\title{
Enhanced Mass Transfer Properties of Porous Nickel Foam as Flow Field for Fuel Cells under Different Working Conditions
}

\author{
Yuzhen Xia, Hui Zhu, Zichen Wang, Feifan Sun, Yousheng Xu, Guilin Hu* \\ Zhejiang University of Science \& Technology, School of Mechanical and Energy Engineering, \\ Hangzhou 310023, China \\ *E-mail: enehg1@163.com
}

doi: $10.20964 / 2021.08 .37$

Received: 11 April 2021 / Accepted: 6 June 2021 / Published: 30 June 2021

\begin{abstract}
High-porosity metal foam, with the advantages, such as low price, good electrical and thermal conductivity, performs high performance as flow field for fuel cells. The mass transfer properties of porous metal foam (PFM) flow fields were investigated under different working temperature and humidity conditions. Fuel cells with both of PFM1 and PFM2, with the area density of 765 and $1500 \mathrm{~g} \cdot \mathrm{m}^{-}$ ${ }^{2}$, respectively, maintained high performances at various states; comparatively that with serpentine flow field (SFF) showed obvious voltage drops at dry and flood state. The area density influence was also discussed, and PMF2 released the largest power density of $96.7 \mathrm{~mW} \cdot \mathrm{cm}^{-2}$, which is $157 \%$ of SFF. Its mass transfer ability was further studied in flooding situation, with $34 \%$ of the flow field volume occupied with water. The porous structure not only enabled the PMF flow field well anti-flood ability, but also the extra water stored in the pores could humidify the membrane at dry state.
\end{abstract}

Keywords: Fuel cell; Metal foam flow field; Humidity; Area density.

\section{$\underline{\text { FULL TEXT }}$}

(C) 2021 The Authors. Published by ESG (www.electrochemsci.org). This article is an open access article distributed under the terms and conditions of the Creative Commons Attribution license (http://creativecommons.org/licenses/by/4.0/). 